\title{
THE THYROID HORMONE-PLASMA PROTEIN COMPLEX IN MAN. I. DIFFERENCES IN DIFFERENT STATES OF THYROID FUNCTION 1, 2
}

\author{
By MILTON W. HAMOLSKY, HASKELL E. ELLISON, AND \\ A. STONE FREEDBERG 3
}

\author{
(From the Department of Medicine, Harvard Medical School, the Medical Research Department \\ of the Yamins Research Laboratories and the Medical Service, Beth Israel \\ Hospital, Boston, Mass.)
}

(Submitted for publication February 14, 1957; accepted June 11, 1957)

The present consensus characterizes thyrotoxicosis, ${ }^{4}$ a disease of unknown etiology, by the quantitative overproduction and release by the thyroid of excessive amounts of normal thyroid hormone (1-4). According to this concept, the distinctive abnormal signs, symptoms, and laboratory findings of hypermetabolism in patients with diffuse toxic goiter are attributed to the effects of increased amounts of the normal hormone upon peripheral tissue metabolism. Plummer (5), among others, proposed an alternate theory, based chiefly upon clinical observations, which ascribed various manifestations of the disease to the effects of 1) an excess of normal hormone, and 2) a qualitatively abnormal hormone, which he suggested was abnormal because of incomplete iodination. In contrast, he suggested that the abnormality in patients with toxic nodular goiter was due solely to an excess of normal thyroid hormone. Salter and Johnston (6) concluded, on the basis of acetone precipitation of acidified sera, that the plasma thyroid hormone in hyperthyroidism differed from thyroxin added in vitro to normal and hypothyroid sera to levels of protein-bound iodine comparable

1 This investigation was supported by research grants (A-140) from the National Institute of Arthritis and Metabolic Diseases of the National Institutes of Health, United States Public Health Service.

2 Portions of this material have been presented at the Annual Meeting of the American Goiter Association, 1954, and the Annual Meeting of the Society for Clinical Investigation, 1955.

Senior Ziskind Fellow, Beth Israel Hospital, Boston, Mass.

4 For this discussion, we refer to a disease associated with increased activity of the autonomic nervous system, characterized by diffuse enlargement of the thyroid gland, eye signs, tachycardia, tremor, hypermetabolism. It includes exophthalmic goiter, hyperthyroidism, Graves', Basedow's, or Parry's disease associated with diffuse toxic goiter. to those observed in hyperthyroidism. Means (1), however, found no biochemical evidence to support Plummer's two-product theory of dysthyroidism. Recent studies $(2,7-10)$, using more precise isotopic and chromatographic methods, have, moreover, failed to indicate any qualitative difference in the hormone circulating in the hyperthyroid as compared to the euthyroid state.

This report deals with three series of experiments employing biological test systems (infusion into dogs and in vitro rat diaphragm "uptake" studies) to investigate the question of the qualitative identity of the thyroid hormone-plasma protein complex in euthyroid and hyperthyroid states in man. The consistent differences observed are not adequately explained by present concepts and indicate 1) a qualitative difference in the nature of the hormone-protein complex in the hyperthyroid as compared to the euthyroid states, or 2) a differential effect of a plasma factor(s) on the disappearance from the plasma or tissue incorporation of the hormone in these two states.

\section{EXPERIMENTAL METHODS AND RESULTS}

Series 1-Infusion of endogenously I-131-labelled human thyroid hormone-Rate of disappearance in dog

A. Methods. Data identifying the donors and the plasma infused are presented in Table I. Eight euthyroid patients (two with thyroid carcinoma and six with angina pectoris or congestive failure), and ten with typical diffuse toxic goiter served as donors. The euthyroid subjects received for therapeutic purposes 10.2 to $61.9 \mathrm{mc}$. I-131, which delivered an estimated thyroid radiation of 1,610 to 55,000 R.E.P. $(11,12)$. The thyrotoxic patients received 4.7 to $15.4 \mathrm{mc}$. I-131, or 8,500 to 15,300 R.E.P. to their thyroid glands. 


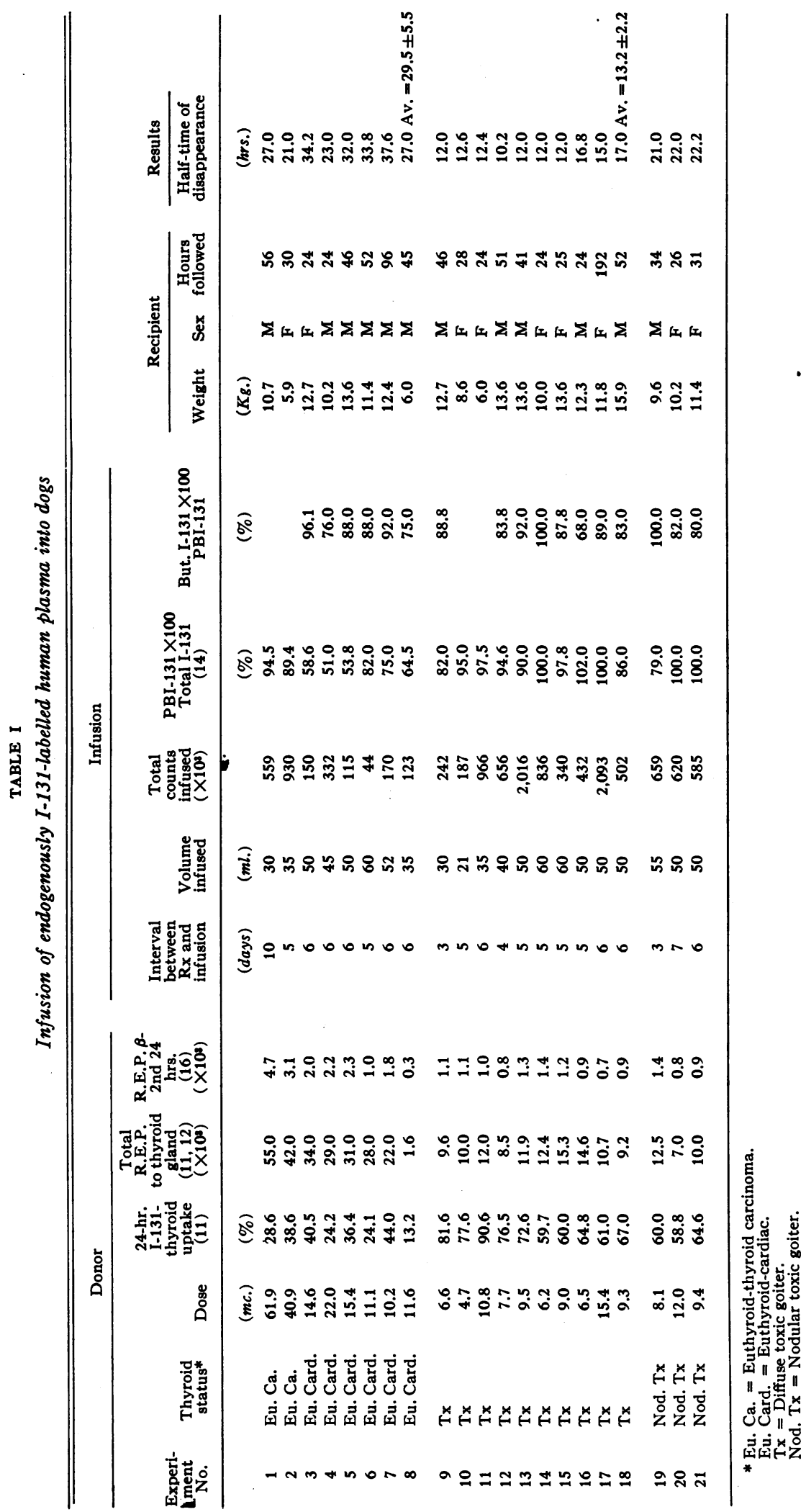




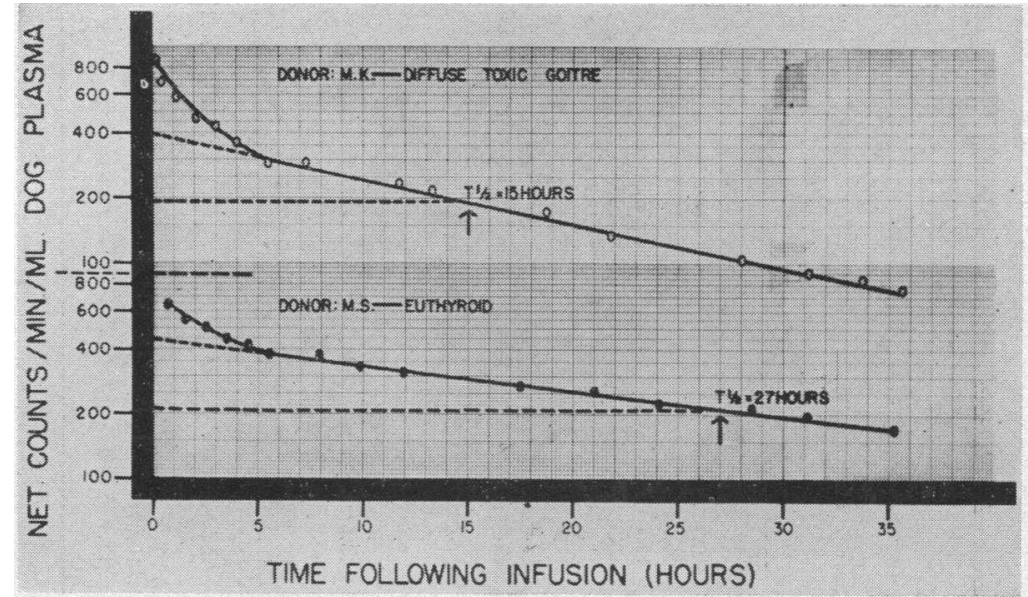

Fig. 1. Comparison of the Early Disappearance in Dogs of ENdogenously I-131-Labelled Thyroid Hormone from a HyperthyroId vs. a Euthyroid Subject

These dosages delivered during the second 24 hours (12) 308 to 4,700 estimated R.E.P. $\beta$ in the euthyroid group, and 670 to 1,365 R.E.P. $\beta$ in the hyperthyroid patients. Following I-131 therapy, blood was removed into acid citrate after intervals ( 5 to 10 days in the euthyroids, 3 to 6 days in the hyperthyroids) shown by previous dialysis, trichloracetic acid precipitation, and butanol extraction studies to permit maximal incorporation of the I-131 into a plasma protein-bound and butanolsoluble (i.e., thyroxin-like) form. Plasma was separated by centrifugation at 3,000 r.p.m. for 30 minutes. All procedures were carried out under sterile precautions. The butanol extractable fraction of the protein-precipitable I-131 was 76 to 96 per cent in the euthyroids and 68 to 100 per cent in the thyrotoxics.

Each plasma was then infused intravenously into an unanesthetized dog. At frequent intervals for the next 24 to 96 hours, blood was removed by femoral vein puncture from the recipient dog and the plasma radioactivity determined (13). Within 30 minutes following the infusion, the radioactivity of the recipient's plasma was virtually 100 per cent protein-precipitable.

The data were subjected to standard graphic analysis, as previously described (14), and as exemplified in Figure 1. Counts per minute per $\mathrm{ml}$. of plasma were plotted as ordinate on semilogarithmic paper against time following infusion as abscissa. Each resultant curve was resolved into straight line components-1) an initial steep slope for six to eight hours which could be resolved mathematically into several components followed by 2) a "slower" exponential component for the next 20 to 40 hours from which the halftimes $\left(t \frac{1}{2}\right)$ of the disappearance of the infused material from the circulation were determined.

B. Results. The results are presented in Table I. The half-times of disappearance in dogs of the radioactivity of the plasma obtained from euthyroid donors ranged from 21.0 to 37.6 hours, with an average of $29.5 \pm 5.5$ hours. In contrast, the half-times of disappearance of radioactivity of the thyrotoxic plasma ranged from 10.2 to 17.0 hours, with an average of $13.2 \pm 2.2$ hours. The difference is very highly significant statistically (the standard error (S.E.) of the difference between the means is 2.2 , and " $t$ " value is 7.41 , and " $\mathrm{p}$ " is $<0.001)$. $^{5}$

In preliminary observations, the half-times of disappearance in dogs of radioactivity of plasma from three patients with nodular toxic goiter fell within the euthyroid range-21.0, 22.0, and 22.2 hours. (See Table I.)

Series 2-Infusion of in vitro I-131-thyroxin-labelled human plasma-Disappearance rate in dog

A. Methods. Data identifying the donors and the plasma infused are presented in Table II. For each of seven paired experiments, plasma was obtained as described above from one euthy-

\footnotetext{
5 Calculated for unpaired data with unequal variance
} and seven degrees of freedom. 
roid subject and one patient with typical diffuse toxic goiter who had received no anti-thyroid therapy. An approximately equal amount of I-131-1-thyroxin ${ }^{6}$ was added, under sterile precautions, to each plasma in a paired run. This varied from 1.0 to $20.0 \mu \mathrm{c}$., representing 0.22 to $14.9 \mu$ g., added to 12 to $22 \mathrm{ml}$. of plasma. After standing at room temperature for the same interval of time, which varied in different experiments, equal volumes of each plasma were infused into unanesthetized dogs. In Experiment No. 7, each dog received morphine sulfate ( $1.5 \mathrm{mg}$. per $\mathrm{Kg}$.) 30 minutes before the infusion. The recipients' plasmas were analyzed at frequent intervals for residual radioactivity (see above). Following an initial rapid decrease in plasma radioactivity for six to eight hours, there was a slower exponential decrease for 30 to 48 hours from which the halftimes of disappearance were obtained as described above and compared in each paired experiment.

B. Results. Data identifying the recipient dogs and the comparison of the disappearance rates of

6 The I-131-1-thyroxine and I-131-1-triiodothyronine were obtained from Abbott Laboratories. Each preparation contained approximately 1 to 6 per cent of the other labelled analogue. each paired experiment are presented in Table II. I-131-thyroxin, added to plasma, is almost immediately incorporated within the protein-precipitable fraction. In both the euthyroid and thyrotoxic plasmas infused, the radioactivity of aliquots was, within the limits of the methods, completely trichloracetic acid-precipitable and butanolsoluble. The euthyroid and hyperthyroid plasmas, therefore, could not be differentiated by these chemical procedures.

In contrast, in the first six experiments, the half-times of disappearance in dogs of the I-131thyroxin-euthyroid plasmas were 17.0 to 30.2 hours, with an average of $23.5 \pm 4.6$ hours; those of the I-131-thyroxin-hyperthyroid plasmas were 10.4 to 15.0 hours, with an average of $12.7 \pm 1.5$ hours. The difference is highly significant-S.E. of the mean of the differences of the paired experiments equals 1.60 , " $t$ " equals $6.75, \mathrm{p}<0.001$. In each paired experiment, the half-time of disappearance of the material obtained from the euthyroid donor was greater than that from the thyrotoxic patient; the ratios (euthyroid to hyperthyroid half-times) ranged from 1.3 to 2.4 . In Experiment 7, in which each animal was pretreated with morphine sulfate, both disappearance

TABLE II

Infusion of in vitro I-131-thyroxin-labelled human plasma into dogs

\begin{tabular}{|c|c|c|c|c|c|c|c|c|c|c|c|}
\hline \multirow{3}{*}{$\begin{array}{c}\text { Expt. } \\
\text { No. }\end{array}$} & \multicolumn{2}{|c|}{ Donor } & \multicolumn{4}{|c|}{ Infusion } & \multicolumn{3}{|c|}{ Recipient } & \multicolumn{2}{|c|}{ Results } \\
\hline & \multirow{2}{*}{$\begin{array}{c}\begin{array}{c}\text { Thyroid } \\
\text { status* }\end{array} \\
\begin{array}{l}\mathrm{Eu} \\
\mathrm{Tx}\end{array}\end{array}$} & \multirow{2}{*}{$\begin{array}{c}\begin{array}{c}24-\text { hr. } \\
\text { I-131 } \\
\text { uptake }\end{array} \\
\% \\
22.5 \\
71.0\end{array}$} & \multirow{2}{*}{$\begin{array}{c}\begin{array}{c}\text { Incuba- } \\
\text { tion } \\
\text { period }\end{array} \\
(\text { hrs. }) \\
\frac{1}{2}\end{array}$} & \multirow{2}{*}{$\begin{array}{c}\begin{array}{c}\text { Amount } \\
\text { infused }\end{array} \\
\left(m l_{.}\right) \\
12\end{array}$} & \multicolumn{2}{|c|}{$\begin{array}{l}\text { I-131-thyroxin } \\
\text { added }\end{array}$} & \multirow{2}{*}{$\begin{array}{l}\text { Sex } \\
\text { F } \\
F\end{array}$} & \multirow{2}{*}{$\begin{array}{c}\text { Wt. } \\
\left(K_{g .}\right) \\
12.3 \\
12.3\end{array}$} & \multirow{2}{*}{$\begin{array}{c}\begin{array}{c}\text { Time } \\
\text { followed }\end{array} \\
(h r s .) \\
30 \\
45\end{array}$} & \multirow{2}{*}{$\begin{array}{c}\boldsymbol{t} \mathbf{3} \\
\text { (hrs.) } \\
18.0 \\
12.0\end{array}$} & \multirow{2}{*}{$\begin{array}{c}\begin{array}{c}\text { Ratio } \\
\text { of } t t^{\prime} \cdot \mathrm{s} \\
\mathrm{Eu} / \mathrm{Tx}\end{array} \\
1.5\end{array}$} \\
\hline & & & & & $\begin{array}{c}\mu c . \\
11.7 \\
11.7\end{array}$ & $\begin{array}{l}\mu g . \\
5.7 \\
5.7\end{array}$ & & & & & \\
\hline 2 & $\begin{array}{l}\mathrm{Eu} \\
\mathrm{Tx}\end{array}$ & $\begin{array}{l}27.0 \\
75.0\end{array}$ & 22 & 18 & $\begin{array}{l}15.1 \\
16.7\end{array}$ & $\begin{array}{l}13.5 \\
14.9\end{array}$ & $\begin{array}{l}\mathbf{M} \\
\mathbf{M}\end{array}$ & $\begin{array}{l}13.6 \\
15.9\end{array}$ & $\begin{array}{l}44 \\
44\end{array}$ & $\begin{array}{l}17.0 \\
13.0\end{array}$ & 1.3 \\
\hline 3 & $\begin{array}{l}\mathrm{Eu} \\
\mathrm{Tx}\end{array}$ & $\begin{array}{l}37.5 \\
73.8\end{array}$ & 2 & 20 & $\begin{array}{l}5.0 \\
5.0\end{array}$ & $\begin{array}{l}1.5 \\
1.5\end{array}$ & $\begin{array}{l}\mathbf{F} \\
\mathbf{M}\end{array}$ & $\begin{array}{l}16.4 \\
16.8\end{array}$ & $\begin{array}{l}144 \\
144\end{array}$ & $\begin{array}{l}30.2 \\
15.0\end{array}$ & 2.0 \\
\hline 4 & $\begin{array}{l}\mathrm{Eu} \\
\mathrm{Tx}\end{array}$ & $\begin{array}{l}21.7 \\
80.2\end{array}$ & $1 \frac{1}{2}$ & 20 & $\begin{array}{l}1.0 \\
1.4\end{array}$ & $\begin{array}{l}0.41 \\
0.57\end{array}$ & $\begin{array}{l}\mathbf{M} \\
\mathbf{M}\end{array}$ & $\begin{array}{l}11.8 \\
11.4\end{array}$ & $\begin{array}{l}48 \\
48\end{array}$ & $\begin{array}{l}24.5 \\
11.5\end{array}$ & 2.1 \\
\hline 5 & $\begin{array}{l}\mathrm{Eu} \\
\mathrm{Tx}\end{array}$ & $\begin{array}{l}17.0 \\
80.7\end{array}$ & 3 & 20 & $\begin{array}{l}3.5 \\
5.3\end{array}$ & $\begin{array}{l}0.22 \\
0.32\end{array}$ & $\begin{array}{l}\mathbf{M} \\
\mathbf{M}\end{array}$ & $\begin{array}{l}15.0 \\
16.4\end{array}$ & $\begin{array}{l}96 \\
96\end{array}$ & $\begin{array}{l}26.5 \\
14.0\end{array}$ & 1.9 \\
\hline 6 & $\begin{array}{l}\text { Eu } \\
\text { Tx }\end{array}$ & $\begin{array}{l}18.0 \\
76.7\end{array}$ & $\frac{3}{4}$ & 22 & $\begin{array}{l}2.3 \\
3.1\end{array}$ & $\begin{array}{l}2.3 \\
3.1\end{array}$ & $\begin{array}{l}\mathbf{F} \\
\mathbf{M}\end{array}$ & $\begin{array}{l}30.9 \\
29.5\end{array}$ & $\begin{array}{l}96 \\
96\end{array}$ & $\begin{array}{l}24.6 \\
10.4\end{array}$ & 2.4 \\
\hline 7 & $\begin{array}{l}\mathrm{Eu} \\
\mathrm{Tx}\end{array}$ & $\begin{array}{l}37.5 \\
73.8\end{array}$ & 24 & 12 & $\begin{array}{l}20.0 \\
15.5\end{array}$ & $\begin{array}{l}6.3 \\
4.9\end{array}$ & $\begin{array}{l}\mathbf{M} \dagger \\
\mathbf{M}\end{array}$ & $\begin{array}{l}13.6 \\
12.7\end{array}$ & $\begin{array}{l}76 \\
76\end{array}$ & $\begin{array}{l}32.5 \\
22.0\end{array}$ & 1.5 \\
\hline
\end{tabular}

* Eu = Euthyroid.

$\mathrm{Tx}=$ Diffuse toxic goiter.

$\dagger$ Each dog received morphine sulphate $1.5 \mathrm{mg}$. per $\mathrm{Kg} .30$ minutes before the infusion. 


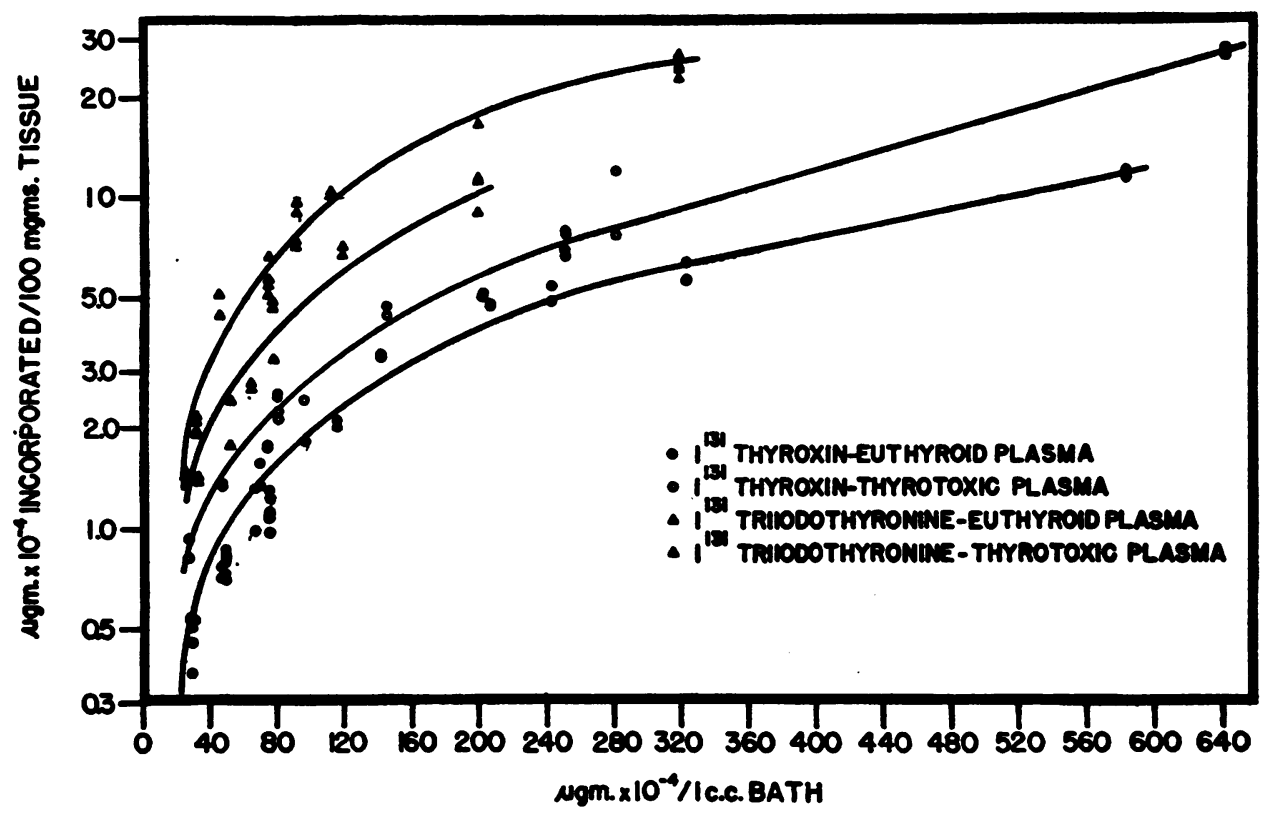

Fig. 2. Five Hour In Vitro "Uptake" by Rat Diaphragm of Labelled Thyroid Hormone Components from Euthyrom and Hyperthyrom Plasmas

Each symbol represents the average of two to four runs with a given plasma.

rates were slower than in untreated animals in the respective groups, but again the disappearance of the euthyroid-labelled plasma was distinctly slower than the hyperthyroid with a ratio similar to that of untreated animals.

Series 3-In vitro I-131-thyroxin- or I-131-triiodothyronine-labelled human plasma-Uptake by rat diaphragm

A. Methods. Varying amounts of I-131-1-thyroxin (I-131-1-THY) or I-131-1-triiodothyronine (I-131-1-TRI) were added to plasmas obtained as described above from euthyroid and untreated thyrotoxic patients. Three-ml. aliquots were then incubated with shaking at $37^{\circ} \mathrm{C}$. under 95 per cent $\mathrm{O}_{2}-5$ per cent $\mathrm{CO}_{2}$ atmospheres in stoppered 10 $\mathrm{ml}$. Erlenmeyer flasks for one-half to two hours. Female Sprague-Dawley rats, weighing 150 to 250 grams, fed on stock laboratory diet, were sacrificed by a sharp blow on the head and exsanguinated via a thoracic incision. The hemidiaphragms were rapidly excised, weighed on a Roller-Smith torsion balance, and placed in a labelled plasma aliquot. When paired experiments were performed, one hemi-diaphragm was placed in the labelled euthyroid plasma, the other in the thyrotoxic plasma. The flasks were then shaken at $37^{\circ} \mathrm{C}$. for varying periods, usually five hours, with replenishment of the 95 per cent $\mathrm{O}_{2}-5$ per cent $\mathrm{CO}_{2}$ atmosphere at one or two hourly intervals. Following this period, each hemi-diaphragm was removed, blotted, washed twice, each time for 20 seconds in $20 \mathrm{ml} .0 .85$ per cent $\mathrm{NaCl}$ solution, with interval and final blotting. The radioactive content was then determined by one of two methods: 1) a direct count of each hemidiaphragm in a well-type scintillation counter, or 2) by dissolving the tissue in hot $2 \mathrm{~N} \mathrm{NaOH}$, drying an aliquot, and counting with conventional end window G-M tubes (13). From the specific activity of the radioactive solutions, the "uptake" from the euthyroid and hyperthyroid plasmas was calculated as $\mu \mathrm{g}$. incorporated per $100 \mathrm{mg}$. wet tissue. The percentage "uptake" per $100 \mathrm{mg}$. wet tissue was also determined by comparison with the radioactivity of the bath solutions before addition of the hemi-diaphragm. Each step was performed at least in duplicate.

To study the effect of the serum protein-bound iodine level, chromatographically pure sodium-1thyroxin or 1-triiodothyronine was added, in varying amounts, to euthyroid plasma, incubated at 
TABLE III

In vitro rat diaphragm uptake of I-131-l-thyroxine and I-131-l-triiodothyronine from human plasma

\begin{tabular}{lll}
\hline \hline & \multicolumn{2}{c}{ Diaphragm uptake (\%/100 mg.) } \\
\cline { 2 - 3 } Thyroid status & \multicolumn{1}{c}{ I-131-thyroxine } & I-131-triodothyronine \\
\hline $\begin{array}{c}\text { Euthyroid (20) } \\
\text { Diffuse toxic } \\
\text { goiter (15) }\end{array}$ & $0.68 \pm 0.11^{*}$ & $1.79 \pm 0.15$ \\
$\begin{array}{c}\text { Nodular toxic } \\
\text { goiter (8) }\end{array}$ & 0.69 (range, 0.58-0.8) & 1.8 (range, 1.3-2.4)
\end{tabular}

* Standard deviation.

room temperature $\left(23\right.$ to $25^{\circ} \mathrm{C}$.) or at $37^{\circ} \mathrm{C}$. for 20 minutes to 24 hours, following which the rat diaphragm uptake of I-131-THY or I-131-TRI was determined, as above, and compared to control uptakes in unenriched plasma. Forty-seven such comparisons were made, in duplicate to quadruplicate, at enriched PBI levels of 9.0 to $20 \mu \mathrm{g}$. per cent.

B. Results. The absolute tissue radioactive content increased with increasing bath concentrations (Figure 2). The percentage "uptake," however, varied within a limited range over a wide range of bath concentrations. In 164 duplicate determinations, using euthyroid plasmas from 123 subjects, labelled by the addition of 15 to $585 \times 10^{-4} \mu \mathrm{g}$. I-131-1-THY per ml., five hour "uptakes" ranged from 0.4 to 0.9 per cent per $100 \mathrm{mg}$. diaphragm, averaged $0.68 \pm 0.13$ per cent. In one determination, the uptake was 1.2 per cent. Similarly, in 140 runs, using euthyroid plasma from 109 subjects labelled by the addition of 12 to $475 \times 10^{-4} \mu \mathrm{g}$. I-131-1-TRI per ml., "uptakes" ranged from 1.2 to 2.5 per cent per 100 mg. tissue, averaged $1.74 \pm 0.27$ per cent.
TABLE IV

Effect of addition of l-thyroxine (stable) to plasma on in vitro rat diaphragm uptake of I-131-l-thyroxine

\begin{tabular}{cc}
\hline \hline Plasma PBI & Diaphragm uptake \\
\hline Mg./100 ml. & $\% / 100$ mg. \\
7.5 (control) & $0.91 ; 0.91 ; 0.86$ \\
10.7 & $0.89 ; 0.91 ; 0.84$ \\
12.0 & $0.81 ; 0.76 ; 0.84$ \\
14.3 & $0.80 ; 0.85 ; 0.85$ \\
\hline
\end{tabular}

In 24 of 26 paired experiments with I-131-THY bath concentrations of 30 to $500 \times 10^{-4} \mu \mathrm{g}$. per $\mathrm{ml}$., the ratios of "uptakes" (hyperthyroid)/euthyroid, at the same bath concentration, ranged from 1.3 to 2.3 with an average of 1.7 ; in the remaining two runs, the ratio was 1.1 . In 25 paired experiments with I-131-TRI ( 46 to $217 \times 10^{-4} \mu \mathrm{g}$. per ml.), the ratios ranged from 1.3 to 2.3 , with an average of 1.9. In one run, the ratio was 1.0. In preliminary experiments, the "uptakes" from eight nodular toxic goiter plasmas were in the euthyroid range (Table III).

The prior addition of chromatographically pure stable 1-thyroxin or stable 1-triiodothyronine to euthyroid plasmas to yield protein-bound iodine plasma concentrations comparable to those of the hyperthyroid state generally failed to increase significantly the subsequent percentage radioactive "uptake" by the rat diaphragm. A typical experiment is shown in Table IV. The various combinations of stable components added and subsequent radioactive "uptakes" are summarized in Table V. Thus, in 30 of 32 comparisons in which PBI levels were increased up to $18.4 \mu \mathrm{g}$. per cent by the addition of 1-thyroxin, there was no significant increased per cent uptake. An increase to

TABLE V

The effect of prior enrichment of euthyroid plasma on diaphragm "uptake"

\begin{tabular}{|c|c|c|c|c|}
\hline $\begin{array}{l}\text { Stable } \\
\text { component } \\
\text { added }\end{array}$ & $\begin{array}{l}\text { PBI levels } \\
\text { attained }\end{array}$ & $\begin{array}{c}\text { Radioactive } \\
\text { label }\end{array}$ & $\begin{array}{c}\text { No. of } \\
\text { runs }\end{array}$ & Effect on \% "uptake"/100 mg. thocue \\
\hline THY & $\begin{aligned} \mu 8 . / 100 \mathrm{ml} . \\
8.6-17.4\end{aligned}$ & I-131-THY & 15 & None \\
\hline THY & $\begin{array}{c}10.4-18.4 \\
17.4 \\
15.8\end{array}$ & I-131-TRI & $\begin{array}{r}15 \\
1 \\
1\end{array}$ & $\begin{array}{l}\text { None } \\
\text { Increased from } 2.0 \text { to } 3.1 \% \\
\text { Increased from } 2.1 \text { to } 2.7 \%\end{array}$ \\
\hline TRI & $8.0-15.0$ & I-131-THY & 6 & None \\
\hline TRI & $\begin{array}{c}8.0-15.0 \\
15.2\end{array}$ & I-131-TRI & $\begin{array}{l}8 \\
1\end{array}$ & $\begin{array}{c}\text { None } \\
\text { Increased from } 2.1 \text { to } 2.8 \%\end{array}$ \\
\hline
\end{tabular}


hyperthyroid "uptake" levels of I-131 TRI was noted in two instances at PBI levels of 15.8 and $17.4 \mu \mathrm{g}$. per cent. In correlative studies, not included in Table $\mathrm{V}$, increased uptakes were consistently obtained at PBI levels above $25 \mu \mathrm{g}$. per cent. The lowest level at which an increase was consistently effected was not determined. Quantitative data on triiodothyronine plasma levels in hyperthyroidism are not definitive. In 14 of 15 runs with $\mathrm{PBI}$ levels increased up to $15 \mu \mathrm{g}$. per cent by the addition of stable triiodothyronine, there was no significant increased per cent "uptake" of I-131-THY or I-131-TRI. In one experiment, an increase in PBI from 5.0 to $15.2 \mu \mathrm{g}$. per cent resulted in an increased "uptake" from 2.1 to 2.8 per cent.

\section{DISCUSSION}

The results of the three series of experiments show striking and consistent differences-1) thyroid hormone from patients with diffuse toxic goiter, labelled either endogenously by prior I-131 administration, or in vitro by the addition of I-131tagged-thyroxin, and infused into dogs, disappeared more rapidly from the circulation than similarly labelled thyroid hormone from euthyroid subjects, and 2) greater amounts of radioactivity were incorporated in vitro by rat diaphragm from thyrotoxic plasma labelled in vitro with I-131-thyroxin or I-131-triiodothyronine than from similarly tagged euthyroid plasma, or from euthyroid plasma artificially enriched to hyperthyroid PBI levels.

These results are not adequately explained by prevailing concepts and indicate 1) a difference in the qualitative nature of the thyroid hormoneprotein complex in hyperthyroidism as compared to the euthyroid state, or 2) the presence of a factor (s) in the plasma of the hyperthyroid individual differing qualitatively or quantitatively in its effect(s) on the disappearance from the circulation, or on tissue uptake, of the labelled hormone moiety.

Series 1 was based on the generally accepted concept that administered I-131 is taken up by the thyroid gland, incorporated therein into the thyroid hormone, which is released to circulate as a protein-bound hormone complex. It has been shown $(8,9,15,16)$ that the administration of very large doses of I-131 results in the release into the circulation of an abnormal I-131-labelled product, probably thyroglobulin, which is proteinprecipitable but not butanol-soluble. Since it was therapeutically necessary to administer larger I-131 doses to our euthyroid subjects than to the patients with hyperthyroidism, the possibility had to be considered that the slower disappearance rate of the euthyroid plasma radioactivity in our studies was due to its content of an abnormally large, I-131-tagged thyroglobulin-like compound. However, the I-131 dosages used and the R.E.P. delivered to the donors' glands were, with the exception of Case 1, Series 1, below the range, that is, 3,600 R.E.P. $\beta$ or more during the second 24 hours, found by Robbins, Rall, Becker, and Rawson (16) to be associated with the release of significant amounts of a thyroglobulin-like material into the circulation. Tubiana (17) found the butanol solubility of serum radioactivity of euthyroid patients receiving 50 to $100 \mathrm{mc}$. to be comparable to that following tracer doses.

The butanol solubility of the plasma was determined in six of the eight euthyroid subjects of Series 1. There was complete overlapping of these values with those of the thyrotoxic plasmas. Therefore, no significant amounts of a thyroglobulin-like fraction appear to have been released from the thyroid glands by the large dosages employed in our euthyroid group as compared to the thyrotoxic group. That the release of such a substance is probably not an important factor in the differences observed is further indicated by the consistent comparative results in Series 2 and 3 which are independent of I-131 radiation effect upon the donor's thyroid gland.

The possibility has been considered that the increased rate of disappearance or tissue "uptake" of the labelled thyrotoxic plasma might be due, in part, to its greater content of an unlabelled protein-bound iodine moiety, i.e., a greater "saturation" of the specific binding plasma protein(s) by thyroxin or triiodothyronine with a resultant "spill-over" of the labelled component onto another plasma protein (e.g., albumin) with a less firm binding capacity. Gross and Leblond (18) have shown, in the rat, that with greatly increasing dosage of infused I-131-thyroxin, from 10 to 2,000 times the estimated physiological range, there was a decrease in the percentage of the dose remaining in the plasma at given time intervals with a cor- 
responding increase in the proportion found in the liver. Our results in Series 3 similarly indicate a positive correlation between the plasma concentrations of the labelled hormone component and the resultant absolute in vitro tissue uptake thereof.

Several recent studies have dealt with the problem of the binding capacity for thyroxin of serum, more specifically its thyroxin-binding protein ("TBP") or globulin ("TBG"). Albright, Larson, and Deiss (19) found this binding capacity to vary inversely with thyroid function, the hypothyroid binding more and the hyperthyroid less thyroxin than normal. The relationship between thyroxin added and that bound by "TBG" was roughly linear at concentrations of 0.05 to $0.4 \mu \mathrm{g}$. per $\mathrm{ml}$., then reached a plateau. "Saturation" of "TBG" was reached at concentrations of approximately 0.15 to $0.2 \mu \mathrm{g}$. per $\mathrm{ml}$. in the hyperthyroid as compared to $0.25 \mu \mathrm{g}$. per ml. in the euthyroid subject. There was distinct overlapping of the amounts bound by the euthyroid and hyperthyroid "TBG" at concentrations up to $0.2 \mu \mathrm{g}$. per $\mathrm{ml}$. Robbins and Rall (20), in contrast, found that the concentration of thyroxin in $\alpha$-globulin did not reach a plateau but continued to increase with increasing addition of thyroxin. The per cent thyroxin bound to alpha globulin at serum thyroxin concentrations of 0.059 to $0.12 \mu \mathrm{g}$. per $\mathrm{ml}$. varied in an apparently random fashion between limits of about 60 and 80 per cent. After a critical evaluation of the significant limitations of the methods, they estimated that saturation of "TBP" occurs at serum thyroxin levels at least two to three times normal. They were not certain whether the values for thyroxin binding differed significantly in a single hyperthyroid serum from those obtained with normals. In a subsequent study using a method of reverse-flow zone electrophoresis, Robbins (21) found the thyroxinbinding capacity of the binding sites for thyroxin in the $\alpha$-globulin in seven normal subjects to range from 0.16 to $0.25 \mu \mathrm{g}$. thyroxin per ml. serum, with a mean of 0.19. Freinkel, Dowling, and Ingbar (22) found that in all sera from hyper-, hypo-, and euthyroid subjects a small percentage of radioactivity migrated with albumin even at the lowest concentrations of thyroxin, and this progressively increased as the concentration of added thyroxin was augmented. They concluded, however, that because "TBP" had not been isolated, could not be measured directly, and had not been characterized as one or several proteins or bindingsites, more quantitative analysis was not justified. In further studies (23), these authors found that the in vitro "uptake" of radiothyroxin by slices of sheep, lambs, calves or beef heart, liver and kidney was dependent upon 1) the amount of tissue, 2) the amount of binding protein in the media, and 3 ) the concentration of thyroxin (stable plus labelled) in the media. Crispell, Kahana, and Hyer (24) found that the in vitro "uptake" of I-131-THY by red blood cells was increased by the addition of very large amounts of stable thyroxin $(50$ to $150 \mu \mathrm{g}$.) or triiodothyronine (100 $\mu \mathrm{g}$.) to $2.0 \mathrm{ml}$. unwashed red blood cells. We have found (25) that prior addition of stable THY or TRI to whole blood increases the in vitro "uptake" of I-131-THY or I-131-TRI by the erythrocytes. This effect, however, increases with increasing time of prior incubation of the blood with the stable component and may not, therefore, be due solely to saturation of the binding protein(s), which effect is not time dependent.

Thus, precise quantitative relationships cannot be made at this time. Although it appears that available binding sites can be saturated at sufficiently high PBI levels, failure to obtain increased per cent in vitro "uptakes" by the enrichment of plasmas to PBI levels found clinically in hyperthyroidism lead us to conclude that our results are not adequately explained on this basis.

Furthermore, between our two groups in Series 1 , there was distinct overlapping of the calculated specific activities of the infused material because of the varying concentrations of plasma radioactivity and amounts of plasma infused (Table I). It was estimated that the amounts of protein-bound iodine complex infused ranged from 1.8 to $3.6 \mu \mathrm{g}$. in the euthyroid group as compared to 3.2 to 9.0 $\mu \mathrm{g}$. in the thyrotoxic group. There was no apparent correlation within either group between the estimated amount of the stable plus labelled proteinbound iodine complex in the infusion and the observed disappearance rate in the recipient.

Further evidence was obtained in Series 2 and 3 that the observed difference in disappearance rates between euthyroid and thyrotoxic plasma in Series 1 was not due solely to differences in the respective amounts of protein-bound iodine compounds. Despite the wide ranges of $\mu \mathrm{g}$. and $\mu \mathrm{c}$. of 
added radioactive materials and the resultant wide ranges of specific activities of the infusions and baths in Series 2 and 3, the disappearance rates of radioactivity and the tissue "uptake" of radioactivity were consistently greater with thyrotoxic than with euthyroid plasmas under comparable experimental conditions. Total "uptake" of thyroxin (labelled plus unlabelled) from thyrotoxic plasma was more than twice that from labelled euthyroid plasmas containing comparable total amounts of thyroxin, calculated with the assumptions that the average PBI of euthyroids is 6.0 $\mu \mathrm{g}$. per cent, that of the hyperthyroids is $15.0 \mu \mathrm{g}$. per cent and that these values represent chiefly thyroxin. Similar estimates of total triiodothyronine "uptake" cannot be made at present because of lack of data quantitating plasma triiodothyronine levels.

The results of the studies in nodular toxic goiter, although preliminary, are of interest. Although these patients could not be differentiated clinically or by standard laboratory methods from patients with diffuse toxic goiter, the disappearance rate of endogenously I-131-labelled thyroid hormone (three patients) and the tissue "uptake" of exogenously labelled plasma (eight patients) fell within the euthyroid range. Such results are consistent with the hypothesis that there is an overproduction of the normal thyroid hormone in certain hyperthyroid patients with a nodular goiter.

Available data are not sufficient to permit precise definition, in qualitative or quantitative terms, of the body compartment(s) involved in our infusion experiments. Extension of these studies to investigate the actual turnover of the infused component requires the establishment of conditions of equilibrium. In certain experiments in Series 1 and 2 , the recipient's plasma radioactivity, beyond 48 hours, decreased at a third, slower exponential rate. Since the thyroid gland was not blocked in our experiments, it is possible that this is due, in part, to the addition to the plasma of "new" hormone, endogenously labelled in the dog's thyroid by the I-131 liberated in the catabolism of the infused, labelled hormone. Because this added hormone is not distinguishable by methods of this study from the infused test hormone, we have limited this analysis of infusion studies to the first 48 hours. Our results, therefore, are not to be interpreted in terms of the ultimate metabolism of the infused hormone, as has been done by Levy, Kelly, Cooper, and Jefferies (26) who demonstrated, in prolonged infusion studies, that the ultimate turnover was dependent upon the metabolic state of the recipient rather than that of the donor.

Despite this limitation, the differences observed between euthyroid and hyperthyroid plasmas under these varied experimental conditions appear significant. They raise the question of the validity of the concept that the essential abnormality in hyperthyroidism is the overproduction of the normal thyroid hormone. While it had been postulated that the circulating thyroid hormone was wholly a thyroxin-protein compound, the studies of Gross and Pitt-Rivers $(2,27,28)$ demonstrating the natural formation and circulation of the calorigenically potent triiodothyronine, have necessitated a re-evaluation of this concept. We have found in preliminary studies (29) that the disappearance rate of I-131-1-triiodothyronine added to euthyroid plasma and infused into a dog is significantly greater than that of equivalent amounts of I-131-1-thyroxin added to an equal aliquot of the same plasma. Rawson et al. (30) have demonstrated, in euthyroid athyreotic humans, that I-131triiodothyronine disappears from the plasma following intravenous administration at rates 2.4 to 4.8 times as rapidly as I-131-thyroxin. Sterling, Lashof, and Man (31) have obtained comparable results in euthyroid subjects. In Series 3 , the rat diaphragm "uptake" of I-131-triiodothyronine was always greater than that of I-131-thyroxin at comparable bath concentrations of both euthyroid and hyperthyroid plasmas. Ratios of "uptake" (I-131triiodothyronine to I-131-thyroxin) of 1.6 to 4.1 , with an average of 3.0 , were obtained in 31 runs in baths containing 30 to $340 \times 10^{-4} \mu \mathrm{g}$. radioactive material per $\mathrm{ml}$. We have also found (32) that, over a wide range of concentrations and incubation times, the "uptake" by rat diaphragm of I-131-1-triiodothyronine in buffer solutions is consistently greater (2.0 to 4.5 times) than that of I-131-1-thyroxin in comparable buffer solutions. Such findings suggest the possibility in hyperthyroidism of delivery to the tissues of a hormone complex containing relatively greater amounts of triiodothyronine or some other as yet unidentified potent component which enters peripheral tissues more rapidly and in greater amounts than does 
thyroxin. This would not explain, however, our observations of greater disappearance rates and tissue incorporation of I-131-thyroxin from thyrotoxic as compared to euthyroid plasma.

Other possibilities which may be of pathogenetic importance in hyperthyroidism are 1) an abnormal linkage, in kind or degree, of the thyroxin or triiodothyronine to a plasma protein component(s), and 2) the effect of a plasma factor(s), either abnormal or present in increased amounts, which increases the rate of utilization of the hormone-protein complex, leading to a compensatory increase in production of the hormone by the thyroid gland to meet the increased demand. Such an effect might be specifically on the utilization of the thyroid hormone, or indirectly mediated. Relevant data on the effects of the infusion of heterologous plasma in animals are scanty. Sanford and Blackford (33) have reported that the injection, in dogs, of thyrotoxic sera or extracts of exophthalmic goiters produced a marked transient drop in blood pressure. Schoenborn (34), however, failed to find any difference in blood pressure response in cats following infusion of extracts of normal and thyrotoxic glands. Preliminary attempts to measure the blood pressure response in our unanesthetized dogs have been unsuccessful. Further studies are necessary to clarify these possibilities.

Experience with the methods used in this study has not been sufficient to permit evaluation of their possible use for diagnostic purposes. Extensive experience with tests of each single parameter of thyroid function has yielded overlapping results when applied to the broad spectrum of various levels of thyroid activity. The methods used in this study, however, do permit investigation of important parameters of thyroid function, concerning which pertinent data are meager. It is believed that their extension and integration with other methods in the over-all study of thyroid physiology and pathology are clearly indicated.

\section{SUMMARY}

1. Three series of experiments were performed to test the generally accepted concept of the biologically qualitative identity of the circulating thy- roid hormone in the normal and hyperthyroid states.

2. The half-times of disappearance of endogenously I-131-labelled euthyroid human thyroid hormone during the first 24 to 48 hours following infusion into the dog ranged from 21.0 to 37.6 hours with an average of $29.5 \pm 5.5$ hours. In comparable experiments using labelled hormone from patients with diffuse toxic goiter, the half-times of disappearance ranged from 10.2 to 17.0 hours, with an average of $13.2 \pm 2.2$ hours. The difference was statistically very highly significant.

3. The half-times of disappearance in the dog of in vitro-labelled I-131-thyroxin euthyroid plasma ranged from 17.0 to 30.2 hours, with an average of $23.5 \pm 4.6$ hours; those for similarly labelled thyrotoxic plasma ranged from 10.4 to 15.0 hours with an average of $12.7 \pm 1.5$ hours. The difference was statistically highly significant.

4. Radioactivity of in vitro-labelled I-131-thyroxin-thyrotoxic plasma and I-131-triiodothyronine-thyrotoxic plasma was incorporated by the rat diaphragm in vitro in amounts averaging 1.7 and 1.9 times that of I-131-1-thyroxin-euthyroid plasma and I-131-triiodothyronine-euthyroid plasma, respectively.

5. The prior enrichment of euthyroid plasma by the addition of 1-thyroxine or 1-triiodothyronine to hyperthyroid PBI levels failed to increase the subsequent in vitro percentage radioactive "uptake" by the rat diaphragm to hyperthyroid levels.

6. In preliminary studies in patients with nodular toxic goiter, the half-times of disappearance of endogenously I-131-labelled thyroid hormone and in vitro rat diaphragm "uptakes" of I-131-1-thyroxin and I-131-1-triiodothyronine fell within the euthyroid range.

7. The results are not adequately explained by the prevailing concept that thyrotoxicosis with diffuse toxic goiter is caused solely by an excess of the normal thyroid hormone. They indicate 1) a qualitative difference in the nature of the circulating hormone-protein complex in hyperthyroidism as compared to the euthyroid state, or 2) a differential effect of a plasma factor(s) on the "peripheral utilization" of thyroid hormone in the two thyroid states.

8. Certain other theoretical implications of these concepts are discussed. 


\section{ACKNOWLEDGMENT}

We wish to express our appreciation to Dr. Mindel Sheps of the Department of Preventive Medicine, Harvard Medical School, for her help in the statistical analysis of the data.

\section{REFERENCES}

1. Means, J. H., The Function of the Thyroid Gland. Springfield, Ill., Charles C Thomas, 1949.

2. Gross, J., and Pitt-Rivers, R., The identification of 3: $5: 3^{\prime}$ 1-triiodothyronine in human plasma. Lancet, 1952, 1, 439.

3. Rosenberg, I. N., The nature of the circulating thyroid hormone in Graves' disease. J. Clin. Invest., 1951, 30, 1.

4. Roche, J., Michel, O., Deltour, G. H., and Michel, R., Sur la thyroglobuline humaine marquée par l'iode radioactif, a l'état normal et dans la maladie de Basedow. Ann. d'endocrinol., 1952, 13, 1.

5. Plummer, H. S., The Function of the Thyroid Gland, Beaumont Foundation. St. Louis, C. V. Mosby, 1925.

6. Salter, W. T., and Johnston, M. W., Tracing the thyroid hormone in peripheral tissues. J. Clin. Endocrinol., 1948, 8, 911.

7. Deiss, W. P., Albright, E. C., and Larson, F. C., A study of the nature of the circulating thyroid hormone in euthyroid and hyperthyroid subjects by use of paper electrophoresis. J. Clin. Invest., 1952, 31, 1000.

8. Robbins, J., and Rall, J. E., Zone electrophoresis in filter paper of serum I-131 after radioiodide administration. Proc. Soc. Exper. Biol. \& Med., 1952, 81, 530.

9. Maurer, W., and Müller, E. R., Zur frage der transportfunktion einzelner serum-eiweiss-fractionen für die organischen jodverbindungen des serums. (Papierelektrophoretische untersuchung von $\mathrm{J}^{\mathrm{I}-1 \mathrm{~m}}$ markierten seren bei niedriger und hoher strahlenbelastung der schilddrüse.) Bioch. Ztschr., 1953, 324, 325.

10. Dingledine, W. S., Pitt-Rivers, R., and Stanbury, J. B., Nature and transport of the iodinated substances of the blood of normal subjects and of patients with thyroid disease. J. Clin. Endocrinol. \& Metab., 1955, 15, 724.

11. Freedberg, A. S., Kurland, G. S., Chamovitz, D. L., and Ureles, A. L., A critical analysis of the quantitative I-131 therapy of thyrotoxicosis. J. Clin. Endocrinol., 1952, 12, 86.

12. Marinelli, L. D., Quimby, E. H., and Hine, G. J., Dosage determination with radioactive isotopes. II. Practical considerations in therapy and protection. Am. J. Roentgenol., 1948, 59, 260.

13. Freedberg, A. S., Ureles, A., and Hertz, S., Serum level of protein-bound radioactive iodine (I-131) in the diagnosis of hyperthyroidism. Proc. Soc. Exper. Biol. \& Med., 1949, 70, 679.

14. Hamolsky, M. W., Freedberg, A. S., Kurland, G. S., and Wolsky, L., The exchangeable thyroid hormonal pool. I. Its magnitude and rate of turnover in various thyroid states in man. J. Clin. Invest., 1953, 32, 453.

15. Tong, W., Taurog, A., and Chaikoff, I. L., Nature of plasma iodine following destruction of the rat thyroid with I-131. J. Biol. Chem., 1952, 195, 407.

16. Robbins, J., Rall, J. E., Becker, D. V., and Rawson, R. W., The nature of the serum iodine after large doses of I-131. J. Clin. Endocrinol. \& Metab., 1952, 12, 856.

17. Tubiana, M., Mesure du temps de renouvellement d'hormone thyroidienne naturelle marquée par le radioiode chez le lapin et chez l'homme. Compt. rend. Soc. de biol., 1951, 145, 1011.

18. Gross, J., and Leblond, C. P., Metabolism of the thyroid hormone in the rat as shown by physiological doses of labelled thyroxine. J. Biol. Chem., 1950, 184, 489.

19. Albright, E. C., Larson, F. C., and Deiss, W. P., Thyroxine binding capacity of serum alpha globulin in hypothyroid, euthyroid and hyperthyroid subjects. J. Clin. Invest., 1955, 34, 44.

20. Robbins, J., and Rall, J. E., Thyroxine-binding capacity of serum in normal man. J. Clin. Invest., 1955, 34, 1324.

21. Robbins, J., Reverse-flow zone electrophoresis. A method for determining the thyroxine-binding capacity of serum protein. Arch. Biochem. \& Biophys., 1956, 63, 461.

22. Freinkel, N., Dowling, J. T., and Ingbar, S. H., The interaction of thyroxine with plasma proteins: Localization of thyroxine-binding protein in Cohn fractions of plasma. J. Clin. Invest., 1955, 34, 1698.

23. Freinkel, N., Ingbar, S. H., and Dowling, J. T., The influence of extracellular thyroxine-binding protein upon the accumulation of thyroxine by tissue slices. J. Clin. Invest., 1957, 36, 25.

24. Crispell, K. R., Kahana, S., and Hyer, H., The effect of plasma on the in vitro uptake or binding by human red cells of radioactive I-131 labelled 1-thyroxine and 1-triiodothyronine. J. Clin. Invest., 1956, 35, 121.

25. Hamolsky, M. W., Stein, M., and Freedberg, A. S., The thyroid hormone-plasma protein complex in man. II. A new in vitro method for study of "uptake" of labelled hormonal components by human erythrocytes. J. Clin. Endocrinol. \& Metab., 1957, 17, 33.

26. Levy, R. P., Kelly, L. W., Jr., Cooper, G. W., and Jefferies, W. McK., The volume of distribution and turnover of endogenously labelled human thyroid hormone from euthyroid and hyperthyroid donors (abstract). J. Clin. Invest., 1955, 34, 948. 
27. Gross, J., and Pitt-Rivers, R., 3:5:3'-triiodothyronine. I. Isolation from thyroid gland and synthesis. Biochem. J., 1953, 53, 645.

28. Gross, J., and Pitt-Rivers, R., $3: 5: 3^{\prime}$ triiodothyronine. II. Physiological activity. Biochem. J., 1953, 53, 652.

29. Hamolsky, M. W., and Freedberg, A. S., Unpublished data.

30. Rawson, R. W., Rall, J. E., Pearson, O. H., Robbins, J., Poppell, H. F., and West, C. D., 1-triiodothyronine versus 1-thyroxine. A comparison of their metabolic effects in human myxedema. Am. J. M. Sc., 1953, 226, 405.
31. Sterling, K., Lashof, J. C., and Man, E. B., Disappearance from serum of $I^{-18 n}$-labeled 1-thyroxine and 1-triiodothyronine in euthyroid subjects. J. Clin. Invest., 1954, 33, 1031.

32. Hamolsky, M. W., Ellison, H. E., and Freedberg, A. S., Unpublished data.

33. Sanford, A. H., and Blackford, J. M., A comparative study of the effects on blood-pressure of the extracts and sera of exophthalmic goiter and of other substances. Collected Papers by the Staff of St. Mary's Hospital, Mayo Clinic, 1913, 492.

34. Schoenborn, S., Zur wirkung der thyreoideastoffe. Arch. f. exper. Path. u. Pharmakol., 1908, 60, 390. 